\title{
REVIEW
}

Open Access

\section{Diosgenin and galactomannans, natural products in the pharmaceutical sciences}

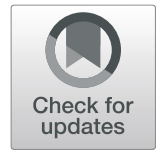

Mohamad Hesam Shahrajabian ${ }^{{ }^{*}}$ (D), Wenli Sun ${ }^{1}$ (D), Diorge Jonatas Marmitt ${ }^{2}$ (D) and Qi Cheng ${ }^{1,3,4}$ (D)

\begin{abstract}
Background: Diosgenin is an isospirostane derivative, which is a steroidal sapogenin and the product of acids or enzymes hydrolysis process of dioscin and protodioscin. Galactomannans are heteropolysaccharides composed of D-mannose and D-galactose, which are major sources of locust bean, guar, tara and fenugreek.

Methods: Literature survey was accomplished using multiple databases including PubMed, Science Direct, ISI web of knowledge and Google Scholar.

Results: Four major sources of seed galactomannans are locust bean (Ceratonia siliqua), guar (Cyamopsis tetragonoloba), tara (Caesalpinia spinosa Kuntze), and fenugreek (T.foenum-graecum). Diosgenin has effect on immune system, lipid system, inflammatory and reproductive systems, caner, metabolic process, blood system, blood glucose and calcium regulation. The most important pharmacological benefits of galactomannan are antidiabetic, antioxidant, anticancer, anticholinesterase, antiviral activities, and appropriate for dengue virus and gastric diseases.
\end{abstract}

Conclusions: Considering the importance of diosgenin and galactomannans, the obtained findings suggest potential of diosgenin and galactomannans as natural products in pharmaceutical industries.

Keywords: Health benefits, Diosgenin, Galactomannans, Natural products

\footnotetext{
* Correspondence: Hesamshahrajabian@gmail.com

${ }^{1}$ Biotechnology Research Institute, Chinese Academy of Agricultural Sciences, Beijing 100081, China

Full list of author information is available at the end of the article
}

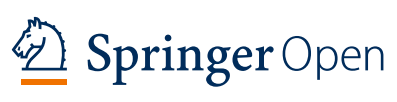

(c) The Author(s). 2021 Open Access This article is licensed under a Creative Commons Attribution 4.0 International License, which permits use, sharing, adaptation, distribution and reproduction in any medium or format, as long as you give appropriate credit to the original author(s) and the source, provide a link to the Creative Commons licence, and indicate if changes were made. The images or other third party material in this article are included in the article's Creative Commons licence, unless indicated otherwise in a credit line to the material. If material is not included in the article's Creative Commons licence and your intended use is not permitted by statutory regulation or exceeds the permitted use, you will need to obtain permission directly from the copyright holder. To view a copy of this licence, visit http://creativecommons.org/licenses/by/4.0/. 


\section{Introduction}

Natural products from herbal medicines, particularly traditional Iranian and Chinese medicines have found to be effective for many diseases [1-4]. Medicinal plants and traditional herbal remedies have been gaining considerable attention in these years because of accessibility, affordability, their safety, promising efficacy and being eco-friendly [5-9]. Galactomannans are heterogeneous polysaccharides comprising a $\beta$ - $(1 \rightarrow 4)$ d-mannose backbone branched with $\alpha-(1 \rightarrow 6)$ linked d-galactose monomeric units. Galactomannans's nature defined by the parameters, such as intrinsic viscosity, M/G ratio, fine structure and average molecular weight, and it is considered as the natural polysaccharides which are used as the stabilizer, emulsifier and thickener in the food industries. Galactomannans belongs to a family of seed gums and present polymers of galactose and mannose. Diosgenin, a triterpenoid having two pentacyclic rings especially found in fenugreek (Trigonellafoenum-graecum L. - Leguminosae) and roots of wild yam (Dioscoreavillosa L. - Dioscoreaceae), and considered as an antihyperglycemic, antidiabetes, antihypertriacylglycerolemia, and antihypercholesterolemic agent, especially in traditional Chinese medicine. It is biosynthesized from cholesterol via the isoprenoid pathway which involves several steps but starts with acetyl CoA. Galactomannans and Diosgenins are main bioactive components of medicinal plants such as fenugreek. The goal of this manuscript is survey on the most important health benefits and pharmaceutical advantages of galactomannan and diosgenin with considering traditional knowledge of natural products.

\section{Galactomannans}

Galactomannans are naturally occurring biocompatible and biodegradable nonionic polysaccharides consisted of mannose and galactose residues, which are commercially isolated from the seeds of guar, carob, fenugreek and tara plants [10-15]. Galactomannans are under investigation for the design of various drug delivery carriers such as matrix tablets, microparticles, nanoparticles, polymeric micelles, hydrogels and different pharmaceutical excipients [16, 17], like galactomannan extracted from Trigonella persica (Boiss.) E. Small (Leguminosae) endosperm which is useful in the medicine and pharmaceutical industry [18]. In green and immature seed of Gleditsia sinensis Lam. (Leguminosae) tree, galactomannan was substituted to a great extent with a mannose to galactose $(\mathrm{M} / \mathrm{G})$ ration of 2.4 from crude polysaccharides [19]. The seed galactomannan of Bauhinia monandra Kurz (Leguminosae), Bauhinia vahlii Wight \& Arn. (Leguminosae), Citrullus colocynthis (L.) Schrad. (Cucurbitaceae), Delonix elata Gamble (Leguminosae), Leucaena leucocephala (Lam.) de Wit (Leguminosae), and Peltophorum pterocarpum (DC.) K. Heyne (Leguminosae) could be explored as an effective alternative to commercial galactomannans for industrial purposes [20-24]. Galactomannans from Prosopis affinis Spreng (Leguminosae), seeds has shown molecular weight distribution and intrinsic viscosity similar to those of commercial gums [25]. Galactomannan from fenugreek attributes depicted a very food candidacy for industrial application [26, 27]. Liu et al. [28] reported that degradation of galactose was slightly easier than that of mannose. Galactomannans of G.sinensis, fenugreek and guar galactomannans, showed a rod-like and fibrous filament network structure [29]. Galactomannans fraction from Gleditsia triacanthos L. (Leguminosae) seeds could become a suitable alternative to be used as a food texture modifier for starch-based products [30]. Coelho et al. [31] showed that galactomannan films have a large potential application into the engineering area and food science, like G. triacanthos extract which has shown to have excellent filmogenic properties [32, 33]. Galactomannan from Sesbania cannabina (Retz.) Pers. (Leguminosae) was applied for fabricate high-strength film [34]. Retama raetam (Forssk.) Webb \& Berthel (Fabaceae) galactomannan can reduce the glycemic index of starchy foods [35]. Galactomannan pretreatment constitutes a novel and promising therapy to decrease local and remote damage triggered by intestinal ischemia-reperfusion injury [36]. Chemical structure of galactomannan has shown in Fig. 1. The major pharmacological effects of galactomanna have been shown in Table 1.

\section{Diosgenin}

Diosgenin (25R-spirost-5-en-3 $\beta$-ol) (Fig. 2) is an important steroid-based compound obtained from the secondary metabolic products of plant species $[45,46]$, which has been proven as an important bioactive drug component due to its anti-cancer activity, anti-cardioprotective activity, anti-diabetic effects, anti-microbial effects, antithrombotic effects, anti-inflammatory and osteoarthritis protective activities [47-52]. Diosgenin mainly exists in plant cells in the form of the ligand of saponin, with its $C 3$

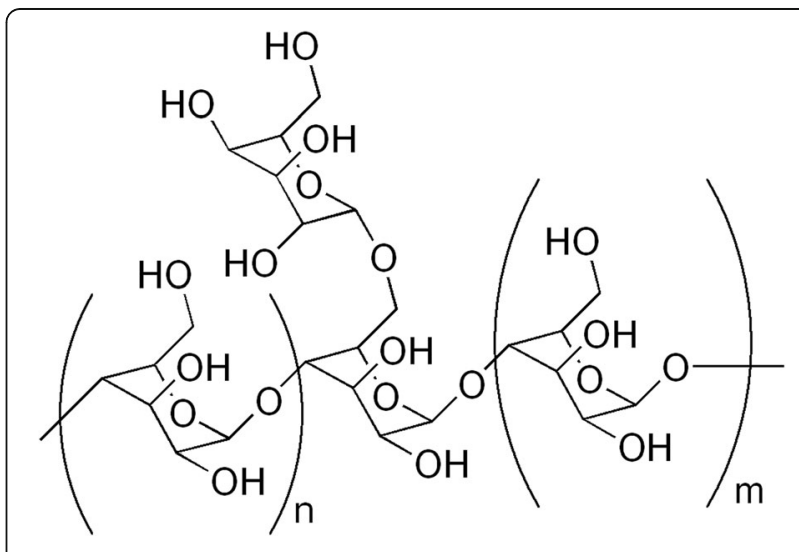

Fig. 1 Chemical structure of galactomannan 
Table 1 The most important pharmacological effects of galactomannan

\begin{tabular}{|c|c|c|}
\hline Health benefits & Key points & Reference \\
\hline $\begin{array}{l}\text { Antidiabetic } \\
\text { activities }\end{array}$ & a. Galactomannan may reduce the glycemic index of starch, and regulates postprandial blood glucose. & [37] \\
\hline Antioxidant activities & a. Galactomannan I and II mainly include D-mannose and D-galactose which have shown antioxidant activities. & {$[38,39]$} \\
\hline Anticancer activities & $\begin{array}{l}\text { a. Galactomannan from Sesbania cannabina has shown anticancer activity which is related to increase caspase-12 } \\
\text { expression. }\end{array}$ & [40] \\
\hline $\begin{array}{l}\text { Anticholinesterase } \\
\text { activities }\end{array}$ & a. Galactomanna II indicated strong anticholinesterase activity. & [39] \\
\hline Antiviral activities & $\begin{array}{l}\text { a. Sulfated galactomannans effectively prevented the infection of cells by viruses and the degree of substitution } \\
\text { and molecular weights. }\end{array}$ & [41] \\
\hline Dengue virus & $\begin{array}{l}\text { a. Galactomannan extracted from Leucaena leucocephala seeds (GML), indicated that GML is a potential } \\
\text { polysaccharide for biomaterials development which could involve interactions between Concanavalia ensiformis } \\
\text { seeds (ConA) in immune system and viruses. }\end{array}$ & [42] \\
\hline Gastric diseases & $\begin{array}{l}\text { a. Galactomannans from Caesalpinia pulcherrima can be basis for new compounds in the treatment of gastric } \\
\text { diseases. }\end{array}$ & [43] \\
\hline
\end{tabular}

and C26 linked to sugar chains via saponin bonds [53]. Diosgenin naturally exists in tubers of many Dioscorea or Costus genus plants and seeds of T.foenum-graecum [54], but Discoreanipponica Makino (Dioscoreaceae), a tuberous herbaceous perennial liana, is widely used as materials for diosgenin production in industries [55]. It is also found in Smilax china L. (Smilacaceae), Heterosmilax japonica Kunth (Smilacaceae), Solanumincanum L. (Solanaceae), Solanum virginianum L. (Solanaceae), Cheilocostusspeciosus (J.Koenig) C.D.Specht (Costaceae) and T. foenum graecum. On the basis in vitro and in vivo studies, diosgenin and its analogs have roles in modulating important molecular targets and signaling pathways such as Phosphoinositide 3-kinase/Protein Kinase B/Mechanistic Target of Rapamycin (PI3K/AKT/mTOR), Janus Kinases/Signal Transducer and Activator of Transcription Proteins (JAK/STAT), Factor Nuclear Kappa B (NF-кB), and Mitogen-Activated Protein Kinase (MAPK), e.g., which have vital role in the development of various diseases [56]. It is a natural phytochemical which can mitigate diabetes induced oxidative stress and dyslipidemia which is important in cardio-metabolic risks by modulating the Peroxisome proliferator-activated receptor (PPARs) [57]. Diosgenin induces apoptosis inInsulin-like Growth Factor-1(IGF-1)-treated thyrocytes through two

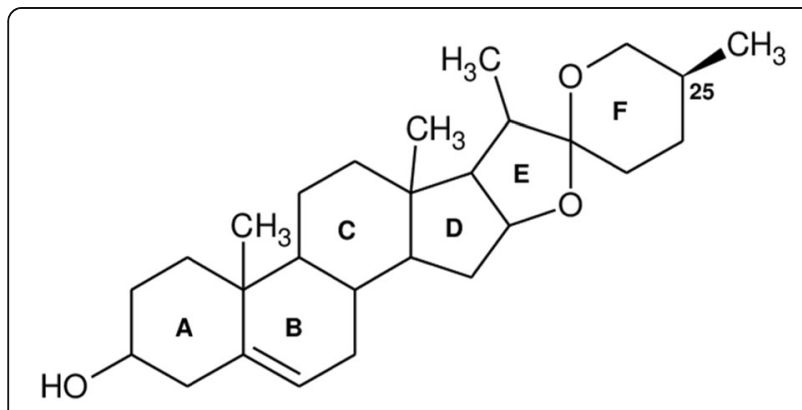

Fig. 2 Chemical structure of diosgenin [44] (Jesus et al. 2016) caspase pathways, namely inhibits FLICE inhibitory proteins (FLIP), and activates Caspase- 8 in FAS related-pathway and increases Reactive Oxygen Species (ROS), regulates the ration of BCL2 Associated X/B-cell lymphoma 2 (BAX/ BCL-2) in mitochondrial pathway [58]. Diosgenin ameliorated endothelial dysfunction through $I_{\kappa} B$ kinase $\beta / I R$ substrate 1-dependent manner (IKK $\beta /$ IRS-1), and improved endothelial insulin signaling under inflammatory conditions which shows its potential application in the treatment for atherosclerosis [59]. Diosgenin has the potential to show high glucose-induced renal proximal tubular fibrosis party by modulating Epithelial-to-Mesenchymal Transition (EMT) pathway [60]. Treatment by diosgenin may provide significant improvement toward preserving hemodynamic changes and alleviating oxidative stress, inflammatory and apoptotic markers induced by monocrotaline in rats and it also prevent monocrotaline-induced changes in nitric oxide production, endothelial and inducible nitric oxide synthase protein expression and histological analysis which shows its importance in pulmonary hypertension [61]. Diosgenin restored moderately decreased sperm motility in D-galactosetreated wistar males and it can be a choice for treatment of mild age-related reproductive dysfunctions [62]. It also shows antinociceptive potential in diabetic rats through lowering oxidative stress and inflammation and improving antioxidant defense system [63]. Zolfaghari et al. [64] reported that the induction of hairy roots considerably increased the production of diosgenin as compared with the plant itself, and they have found that by converting dioscin to diosgenin, the non-specific beta-glucosidase activity of bacterial genes may lead to higher accumulation of diosgenin in hairy roots of T. foenum-graecum. Diosgenin may inhibit melanogenesis through the activation of the Phosphatidylinositol-3-kinase (PI3K) pathway, and it may be considered as an effective inhibitor of hyperpigmentation [65]. Chemical structure of diosgenin has shown in Fig. 2. The most important pharmacological effects of diosgenin are shown in Table 2. 
Table 2 The most important pharmacological effects of diosgenin

\begin{tabular}{|c|c|c|}
\hline Health benefits & Key points & Reference \\
\hline \multirow[t]{4}{*}{ Anti-diabetic effects } & a. Diosgenin could have a beneficial role against aortic damage induced by oxidative stress in diabetic state. & [66-69] \\
\hline & b. Diosgenin demonstrated anti-glycating properties and it improved the renal function in diabetic rats. & \\
\hline & $\begin{array}{l}\text { c. Diosgenin can effectively regulate the related targets and pathways of glycolipid metabolism, apoptosis, } \\
\text { inflammation and oxidative stress to improve diabetes and it complications. }\end{array}$ & [70] \\
\hline & $\begin{array}{l}\text { d. Diosgenin counteracted the effect of diabetes on the growth plate and cancellous bone microarchitecture in } \\
\text { the distal femur, indicating some limited beneficial impact on the skeleton. }\end{array}$ & [71] \\
\hline \multirow[t]{2}{*}{$\begin{array}{l}\text { Anti-inflammatory } \\
\text { activity }\end{array}$} & $\begin{array}{l}\text { a. Diosgenin modulates adipokine expression in perivascular adipose tissue (PVAT) against inflammation which } \\
\text { depends on AMPK. }\end{array}$ & {$[72,73]$} \\
\hline & $\begin{array}{l}\text { b. Diosgenin down-regulated the inflammatory mediators which prevent the atherosclerotic disease progression } \\
\text { and concomitant suppression of inflammatory mediators in liver and brain. }\end{array}$ & [74] \\
\hline Anti-Obesity effects & $\begin{array}{l}\text { a. Dioscin and its aglycone, diosgenin, both suppressed the time-dependent increase of blood triacylglycerol } \\
\text { level when orally injected with corn oil to mice, which shows their inhibitory potential against fat absorption. }\end{array}$ & [75] \\
\hline \multirow[t]{2}{*}{ Anti-oxidant effects } & a. Diosgenin with antioxidant function may show potential to improve cardiac tissue abnormalities. & [76] \\
\hline & b. Diosgenin shows concentration dependent antioxidant potential. & {$[77,78]$} \\
\hline $\begin{array}{l}\text { Anti-proliferative } \\
\text { effects }\end{array}$ & $\begin{array}{l}\text { a. The azasteroidal compounds from diosgenin showed lower cytotoxicity and lactam-type enamide derivative } \\
\text { showed activity in cancer cell line MDA-MB- } 231 \text {. }\end{array}$ & [79] \\
\hline \multirow[t]{2}{*}{ Anti-psoriasis effects } & $\begin{array}{l}\text { a. In animal studies, diosgenin attenuated psoriatic lesions on mice by inhibiting vascular formation partially by } \\
\text { reducing the VEGF-a expression in keratinocytes. }\end{array}$ & {$[80]$} \\
\hline & $\begin{array}{l}\text { b. Diosgenin down-regulated pro-inflammatory cytokines through TLR4/Myd88 inhibition and up-regulated sev- } \\
\text { eral differentiation markers' expression in HaCaT cells. }\end{array}$ & {$[80]$} \\
\hline \multirow[t]{4}{*}{ Anti-cancer effects } & $\begin{array}{l}\text { a. Diosgenin is a novel blocker of the STAT3 activation pathway, with a potential role in the treatment of } \\
\text { hepatocellular carcinoma (HCC) and other cancers. }\end{array}$ & {$[81,82]$} \\
\hline & $\begin{array}{l}\text { b. Diosgenin has shown inhibitory activity on human breast cancer MDA-MB- } 231 \text { cell migration, and inhibited ac- } \\
\text { tion polymerization, Vav2 phosphorylation and Cdc42 activation which shows its therapeutic potential for human } \\
\text { breast cancer metastasis therapy. }\end{array}$ & [83] \\
\hline & $\begin{array}{l}\text { c. Inhibition of Enhancer of zeste homo-log2 }(\mathrm{EZH} 2) \text { by diosgenin could be a promising therapeutic method for } \\
\text { pancreatic cancer }(\mathrm{PC}) \text { treatment as } \mathrm{EZH} 2 \text { signaling is closely associated with the anti-tumor characteristics of di- } \\
\text { osgenin in PC cells. }\end{array}$ & {$[84]$} \\
\hline & $\begin{array}{l}\text { e. Diosgenin and its glycosidic derivatives are promising anti-cancer compounds as they are compounds with } \\
\text { low necrotic activity and selective action. }\end{array}$ & {$[85,86]$} \\
\hline Anti-tumour effects & $\begin{array}{l}\text { a. A set of diosgenin compounds should be considered as a promising scaffold for their abilities as anticancer } \\
\text { and immunomodulatory agents. }\end{array}$ & {$[87,88]$} \\
\hline $\begin{array}{l}\text { Hepatoprotective } \\
\text { effects }\end{array}$ & $\begin{array}{l}\text { a. Administration of diosgenin may lead to reduction of liver injury indices and oxidative stress and inflammatory } \\
\text { events. }\end{array}$ & {$[89]$} \\
\hline $\begin{array}{l}\text { Improve female } \\
\text { reproduction }\end{array}$ & $\begin{array}{l}\text { a. Phytoestrogen diosgenin promotes basic ovarian cell functions (proliferation, apoptosis, steroid, and peptide } \\
\text { hormone release). }\end{array}$ & {$[90]$} \\
\hline Multipe sclerosis & $\begin{array}{l}\text { a. Diosgenin alleviated the progression of experimental autoimmune encephalomyelitis with reduction in central } \\
\text { nervous system inflammation and demyelination. }\end{array}$ & [91] \\
\hline Skin aging & $\begin{array}{l}\text { a. A restoration of keratinocyte proliferation in aged skin, showed that diosgenin may have potential to be } \\
\text { considered as a safe health food for climacteric. }\end{array}$ & {$[92]$} \\
\hline Wound healing & $\begin{array}{l}\text { a. Genipin crosslinked gelatin/diosgenin-nanocellulose hydrogels showed excellent antibacterial effect towards } \\
\text { Gram + and - bacteria, and it is suitable in wound healing. }\end{array}$ & [93] \\
\hline
\end{tabular}

\section{Conclusion}

Traditional herbal medicines have been considered as a source of curative remedy due to health promote and prevent diseases, and plants are invaluable sources of new drugs. Galactomannans represent one of the most versatile classes of available materials for applications in many sectors specially pharmaceuticals. It is a group of storage polysaccharides from various plants which reserve energy for germination in the endosperm. They are with rigid hydrophilic backbone (polymannose, or mannan), and grafted galactose units. They are often used in various forms for human consumption. Four major sources of seed galactomannans are locust bean (Ceratonia siliqua), guar (Cyamopsis tetragonoloba), tara (Caesalpinia spinosa Kuntze), and fenugreek (T.foenumgraecum). The most important pharmacological benefits of galactomannan are antidiabetic, antioxidant, anticancer, anticholinesterase, antiviral activities, and appropriate for dengue virus and gastric diseases. A steroidal sapogenin, occurs in plants such as Dioscoreaalata, 
Smilax china, and T. foenum-graecum is diosgenin. Diosgenin, a triterpenoid having two pentacyclic rings. The most important health benefits of diosgenin are anti-diabetic, anti-inflammatory, anti-obesity, antioxidant, anti-proliferative, anti-psoriasis, anti-cancer, antitumour, and hepatoprotective effects; it can also improve female reproduction, multiple sclerosis, and appropriate for skin aging and wound healing.

\section{Acknowledgments}

Not applicable.

\section{Authors' contributions}

All author(s) contributed equally to literature research, writing manuscript, etc. The author(s) read and approved the final manuscript.

\section{Availability of data and materials}

Not applicable.

\section{Declarations}

\section{Ethics approval and consent to participate}

Not applicable.

\section{Consent for publication}

The authors consent for the publication of this review.

\section{Competing interests}

The authors declare that they have no potential conflicts of interest.

\section{Author details}

'Biotechnology Research Institute, Chinese Academy of Agricultural Sciences, Beijing 100081, China. ${ }^{2}$ PostgraduatePorgram in Biotechnology, University of Taquari Valley- Univates, Lajeado, RS, Brazil. ${ }^{3}$ College of Life Sciences, Hebei Agricultural University, Baoding 071000, Hebei, China. ${ }^{4}$ Global Alliance of HeBAU-CLS\&HeQiS for BioAl-Manufacturing, Baoding 071000, Hebei, China.

Received: 18 February 2021 Accepted: 1 June 2021

Published online: 07 June 2021

\section{References}

1. Sun W, Shahrajabian MH, Cheng Q. Anise (Pimpinella anisum L.), a dominant spice and traditional medicinal herb for both food and medicinal purposes. Cogent Biol. 2019;5(1673688):1-25.

2. Sun $\mathrm{W}$, Shahrajabian $\mathrm{MH}$, Cheng $\mathrm{Q}$. The insight and survey on medicinal properties and nutritive components of shallot. J Med Plant Res. 2019; 13(18):452-7.

3. Shahrajabian MH, Sun W, Soleymani A, Cheng Q. Traditional herbal medicines to overcome stress, anxiety and improve mental health in outbreaks of human coronaviruses. Phytother Res. 2020;2020(1):1-11.

4. Shahrajabian $\mathrm{MH}$, Sun $\mathrm{W}$, Cheng Q. Exploring Artemisia annua L., artemisinin and its derivatives, from traditional Chinese wonder medicinal science. Not Bot Horti Agrobot Cluj Napoca. 2020;48(4):1719-4. https://doi.org/10.15835/ nbha48412002.

5. Sun W, Shahrajabian M, Cheng Q. Health benefits of wolfberry (Gou Qi Zi) on the basis of ancient Chinese herbalism and western modern medicine. Avicenna J Phytomed. 2021a. https://doi.org/10.22038/AJP.2020.17147.

6. Sun W, Shahrajabian MH, Cheng Q. Fenugreek cultivation with emphasis on historical aspects and its uses in traditional medicine and modern pharmaceutical science. Mini Rev Med Chem. 2021b;21:1-7. https://doi.org/1 $0.2174 / 1389557520666201127104907$

7. Shahrajabian MH, Sun W, Cheng Q. Chemical components and pharmacological benefits of basil (Ocimum Basilicum): a review. Int J Food Prop. 2020c;23(1):1961-70. https://doi.org/10.1080/10942912.2020.1828456.

8. Shahrajabian MH, Sun W, Cheng Q. Traditional herbal medicine for the prevention and treatment of cold and flu in the autumn of 2020 overlapped with COVID-19. Nat Prod Commun. 2020d;15(8):1-10.

9. Shahrajabian $\mathrm{MH}$, Sun $\mathrm{W}$, Shen $\mathrm{H}$, Cheng Q. Chinese herbal medicine for SARS and SARS-CoV-2 treatment and prevention, encouraging using herbal medicine for COVID-19 outbreak. Acta Agric Scand Sect B Soil Plant Sci. 2020e;70(5):437-43.

10. Gresta F, Ceravolo G, Lo Preti V, D'Agata A, Rao R, Chiofalo B. Seed yield galactomannan content and quality traits of different guar (Cyamopsis tetragonoloba L.) genotypes. Ind Crops Prod. 2017;107:122-9.

11. Gadkari PV, Reaney MJT, Ghosh S. Assessment of gelation behavior of fenugreek gum and other galactomannans by dynamic viscoelasticity, fractal analysis and temperature cycle. Int J Biol Macromol. 2019;126:337-44. https://doi.org/10.1016/j.ijbiomac.2018.12.132.

12. Zhang $\mathrm{S}$, Fan $\mathrm{M}, \mathrm{Ye} \mathrm{G}$, Zhang $\mathrm{H}$, Xie J. Biorefinery of dioscorea composta Hemsl with ferric chloride for saponins conversion to diosgenin and recycling the waste to biomethane. Ind Crop Prod. 2019;135:122-9. https:// doi.org/10.1016/j.indcrop.2019.04.040.

13. Kontogiorgos V. Galactomannans (guar, locust bean, fenugreek, Tara). Encyc Food Chemi. 2019;2019:109-13.

14. Da Silva LM, Araujo LFS, Alvez RC, Ono L, Sa DAT, da Cunha PLR, et al. Promising alternative gum: Extraction, characterization, and oxidation of the galactomannan of Cassia fistula. Int J Biol Macromol. 2020;165(Part A):436-44.

15. Di J, Liu B, Song $X$. The galactose oxidase air oxidation of galactomannans for use as paper strengthening agents. J Wood Chem Technol. 2020;40(2): 105-15.

16. Padinjarathil H, Joseph MM, Unnikrishnan BS, Preethi GU, Shiji R, Archana MG, et al. Galactomannan endowed biogenic silver nanoparticles exposed enhanced cancer cytotoxicity with excellent biocompatibility. Int J Biol Macromol. 2018;118(Part A):1174-82.

17. Yadav $\mathrm{H}$, Maiti $\mathrm{S}$. Research progress in galactomannan-based nanomaterials: synthesis and application. Int J Biol Macromol. 2020;163:2113-26. https://doi. org/10.1016/j.ijbiomac.2020.09.062.

18. Bakhshy E, Zarinkamar F, Nazari M. Isolation, qualitative and quantitative evaluation of galactomannan during germination of Trigonella persica (Fabaceae) seed. Int J Biol Macromol. 2019;137:286-95. https://doi.org/10.1 016/j.jijbiomac.2019.06.225

19. Liu Y, Xu W, Lei F, Li P, Jiang J. Comparison and characterization of galactomannan at different developmental stages of Gleditsia sinensis lam. Carbohydr Poly. 2019;223:115127. https://doi.org/10.1016/j.carbpol.2019.11 5127

20. Nwokocha LM, Senan C, Williams PA, Yadav MP. Characterization and solution properties of a galactomannan from Bauhinia monandra seeds. Int J Biol Macromol. 2017;101:904-9. https://doi.org/10.1016/j.ijbiomac.2 017.03.105.

21. Kouadri I, Layachi A, Makhlouf A, Satha H. Optimization of extraction process and characterization of water-soluble polysaccharide (galactomannan) from Algerian biomass; Citrullus colocynthis seeds. Int J Polym Anal Charact. 2018;23(4):362-75. https://doi.org/10.1080/1023666X.2 018.1455343.

22. Jamir K, Badithi N, Venumadhav K, Seshagirirao K. Characterization and comparative studies of galactomannans from Bauhinia vahlii, Delonixelata, and Peltophorumpterocarpum. Int J Biol Macromol. 2019;134:498-506. https://doi.org/10.1016/j.ijbiomac.2019.05.080.

23. Mittal N, Kaur G. Leucaena leucocephala (Lam.) galactomannan nanoparticles: Optimization and characterization for ocular delivery in glaucoma treatment. Int J Biol Macromol. 2019:139:1252-62.

24. Rodriguez-Canto W, Chel-Guerrero L, Fernandez WA, Aguilar-Vega M. Delonix regia galactomannan hydrolysates: rheological behavior and physicochemical characterization. Carbohydr Polym. 2019;206:573-82. https://doi.org/10.1016/j.carbpol.2018.11.028.

25. Vilaro P, Bennadji Z, Budelli E, Moyna G, Panizzolo L, Ferreira F. Isolation and characterization of galactomannans from Prosopis affinis as potential gum substitutes. Food Hydrocoll. 2018;77:711-9. https://doi.org/10.1016/j. foodhyd.2017.10.038.

26. Rashid F, Hussain S, Ahmed Z. Extraction purification and characterization of galactomannan from fenugreek for industrial utilization. Carbohydr Polym. 2018;180:88-95. https://doi.org/10.1016/j.carbpol.2017.10.025.

27. Ponzini E, Natalello A, Usai F, Bechmann M, Peri F, Muller N, et al. Structural characterization of aerogels derived from enzymatically oxidized galactomannans of fenugreek, sesbania and guar gums. Carbohydr Polym. 2019:207:510-20. https://doi.org/10.1016/j.carbpol.2018.11.100.

28. Liu Y, Lei F, He L, Xu W, Jiang J. Comparative study on the monosaccharides of three typical galactomannans hydrolyzed by different methods. Ind Crop Prod. 2020a;157:112895. https://doi.org/10.1016/j.indcrop.2020.112895. 
29. Liu Y, Lei F, He L, Xu W, Jiang J. Physicochemical characterization of galactomannans extracted from seeds of Gleditsiasinensis lam and fenugreek. Comparison with commercial guar gum. Int J Biol Macromol. 2020b;158:1047-54. https://doi.org/10.1016/j.ijbiomac.2020.04.208.

30. Loser U, Iturriaga L, Ribotta PD, Barrera GN. Combined systems of starch and Gleditsia triacanthos galactomannans: thermal and gelling properties. Food Hydrocoll. 2021;116:106378.

31. Coelho GO, Batista MJA, Avila AF, Franca AS, Oliveira LS. Development and characterization of biopolymeric films of galactomannans recovered from spent coffee grounds. J Food Eng. 2021;289:110083. https://doi.org/10.1016/ j.jfoodeng.2020.110083.

32. Gonzalez A, Barrera GN, Galimberti PI, Ribotta PD, Igarzabal CIA Development of edible films prepared by soy protein and the galactomannan fraction extracted from Gleditsia triacanthos (Fabaceae) seed. Food Hydrocoll. 2019;97:105227. https://doi.org/10.1016/j.foodhyd.201 9.105227.

33. Zhao N, Chai Y, Wang T, Wang K, Jiang J, Yang H-Y. Preparation and physical/chemical modification of galactomannan film for food packaging. Int J Biol Macromol. 2019;137:1060-7. https://doi.org/10.1016/j.ijbiomac.201 9.07.048.

34. Tao Y, Huang C, Lai C, Huang C, Yong Q. Biomimetic galactomannan/ bentonite/graphene oxide film with superior mechanical and fire retardant properties by borate cross-linking. Carbohydr Polym. 2020;245:116508. https://doi.org/10.1016/j.carbpol.2020.116508.

35. Chouaibi M, Rezig L, Lakoud A, Boussaid A, Hassouna M, Ferrari G, et al. Exploring potential new galactomannan source of Retamareatam seeds for food, cosmetic and pharmaceuticals: characterization and physical, emulsifying and antidiabetic properties. Int J Biol Macromol. 2019;124:116776. https://doi.org/10.1016/j.ijbiomac.2018.12.007.

36. Stringa P, Toledano V, Papa-Gobbi R, Arreola M, Largo C, Machuca M, et al. Galactomannan as a potential modulator of intestinal ischemia-reperfusion injury. J Surg Res. 2020;249:232-40. https://doi.org/10.1016/j.jss.2019.10.027.

37. Sun M, Sun Y, Li Y, Liu Y, Liang J, Zhang Z. Physical properties and antidiabetic potential of a novel galactomannan from seeds of Gleditsia japonica var. delavayi. J Funct Foods. 2018;46:546-55. https://doi.org/10.101 6/j.jff.2018.05.027.

38. Gu J, Pei W, Tang S, Yan F, Peng Z, Huang C, et al. Procuring biologically active galactomannans from spent coffee ground (SCG) by autohydrolysis and enzymatic hydrolysis. Int J Biol Macromol. 2020;149:572-80. https://doi. org/10.1016/j.jibiomac.2020.01.281.

39. Tel-Cayan G, Muhammad A, Deveci E, Duru ME, Ozturk M. Isolation, structural characterization, and biological activities of galactomannans from Rhizopogonluteolus and Ganoderma adspersum mushrooms. Int J Biol Macromol. 2020;165(Part B):2395-403.

40. Zhou M, Yang L, Yang S, Zhao F, Xu L, Yong Q. Isolation, characterization and in vitro anticancer activity of an aqueous galactomannan from the seed of Sesbania cannabina. Int J Biol Macromol. 2018;113:1241-7. https://doi. org/10.1016/j.ijbiomac.2018.03.067.

41. Muschin T, Budragchaa D, Kanamoto T, Nakashima H, Ichiyama K Yamamoto $\mathrm{N}$, et al. Chemically sulfated natural galactomannans with specific antiviral and anticoagulant activities. Int J Biol Macromol. 2016:89: 415-20. https://doi.org/10.1016/j.ijbiomac.2016.05.005.

42. Valenga F, Petri DFS, Lucyszyn N, Jo TA, Sierakowski MR. Galactomannan thin films as supports for the immobilization of Concanavalin a and/or dengue viruses. Int J Biol Macromol. 2012;50(1):88-94. https://doi.org/10.101 6/j.jijbiomac.2011.10.005.

43. Marques FDC, Pantoja PDS, Matos VEA, Silva RO, Damasceno SRBD, Franco $A X$, et al. Galactomannan from the seeds of Caesalpiniapulcherrima prevents indomethacin-induced gastrointestinal damage via neutrophil migration. Int J Biol Macromol. 2019;141:68-75. https://doi.org/10.1016/j.ijbiomac.2019.08.193.

44. Jesus M, Martins APJ, Gallardo E, Silvestre S. Diosgenin: Recent highlights on pharmacology and analytical methodology. J Anal Methods Chem. 2016; 4156293:16.

45. Ebrahimibasabi E, Ebrahimi A, Momeni M, Amerian MR. Elevated expression of diosgenin-related genes and stimulation of the defense system in Trigonellafoenum-graecum (fenugreek) by cold plasma treatment. Sci Hortic. 2020;271:109494. https://doi.org/10.1016/j.scienta.2020.109494.

46. Shen B, Yu X, Zhang F, Jiang W, Yuan H, Pan Z, et al. Green production of diosgenin from alcoholysis of dioscoreazingiberensis C. H wright by a magnetic solid acid. J Clean Prod. 2020;271:122297.
47. Jung D-H, Park H-J, Byun H-E, Park Y-M, Ki T-W, Kim B-O, et al. Diosgenin inhibits macrophage-derived inflammatory mediators through downregulation of CK2, JNK, NF-KB and AP-1 activation. Int Immunopharmacol. 2010;10(9):1047-54. https://doi.org/10.1016/j.intimp.2010.06.004.

48. Lepage C, Leger DY, Bertrand J, Martin F, Beneytout JL, Liagre B. Diosgenin induces death receptor-5 through activation of p38 pathway and promotes TRAlL-induced apoptosis in colon cancer cells. Cancer Lett. 2011;301(2):193202. https://doi.org/10.1016/j.canlet.2010.12.003.

49. Lopez EP-F, Qin-tong W, Wei W, Jornet PL. Potential chemotherapeutic effects of diosgenin, zoledronic acid and epigallocatechin-3-gallate on PE/ CA-PJ15 oral squamous cancer cell line. Arch Oral Biol. 2017;82:141-6. https://doi.org/10.1016/j.archoralbio.2017.05.023.

50. Khosravi Z, Sedaghat R, Baluchnejadmojarad T, Roghani M. Diosgenin ameliorates testicular damage in streptozotocin-diabetic rats through attenuation of apoptosis, oxidative stress, and inflammation. Int Immunopharmacol. 2019;70:37-46. https://doi.org/10.1016/j.intimp.2019.01.047.

51. Zhang Z, Wang H, Chen T, Zhang H, Liang J, Kong W, et al. Synthesis and structure characterization of sulfated galactomannan from fenugreek gum. Int J Biol Macromol. 2019;125:1184-91. https://doi.org/10.1016/j.ijbiomac.201 8.09.113.

52. Biswas D, Nazir R, Biswas $P$, Kumar V, Nandy S, Mukherjee A, et al. Endophytic sources of diosgenin, a natural steroid with multiple therapeutic values. S Afr J Bot. 2020;134:119-25. https://doi.org/10.1016/j.sajb.2020.04.009.

53. Wei M, Bai Y, Ao M, Jin W, Yu P, Zhu M, et al. Novel method utilizing microbial treatment for cleaner production of diosgenin from Dioscoreazingiberensis C.H. Wright (DZW). Bioresour Technol. 2013;146:54955. https://doi.org/10.1016/j.biortech.2013.07.090

54. Yu C, Li Z, Yin H, Xia G, Shen Y, Yang H, et al. Green production of diosgenin from Discoreanipponica Makino tubers based on pressurized biphase acid hydrolysis via response surface methodology optimization. Green Chem Lett Rev. 2019;12(1):79-88. https://doi.org/10.1080/17518253.2 019.1579370.

55. Zhang C, Wang Y, Yang Z, Xu M. Chlorine emission and dechlorination in co-firing coal and the residue from hydrochloric acid hydrolysis of Dioscorea zingiberensis. Fuel. 2006;85(14-15):2034-40. https://doi.org/10.1016/j.fuel.2 006.04.009.

56. Parama D, Boruah M, Yachna K, Rana V, Banik K, Harsha C, et al. Diosgenin, a steroidal saponin, and its analogs: effective therapies against different chronic diseases. Life Sci. 2020;260:1 18182. https://doi.org/10.1016/j.lfs.202 0.118182 .

57. Sangeetha MK, Mal NSS, Atmaja K, Sali VK, Vasanthi HR. PPAR's and Diosgenin a chemico biological insight in NIDDM. Chem Biol Interact. 2013; 206(2):403-10. https://doi.org/10.1016/j.cbi.2013.08.014.

58. Mu S, Tian X, Ruan Y, Liu Y, Bian D, Ma C, et al. Diosgenin induces apoptosis in IGF-1-stimulated human thyrocytes through two caspase-dependent pathways. Biochem Biophys Res Commun. 2012:418(2):347-52. https://doi. org/10.1016/j.bbrc.2012.01.024.

59. Liu K, Zhao W, Gao X, Huang F, Kou J, Liu B. Diosgenin ameliorates palmitate-induced endothelial dysfunction and insulin resistance via blocking IKKß and IRS-1 pathways. Atherosclerosis. 2012;223(2):350-8. https://doi.org/10.1016/j.atherosclerosis.2012.06.012.

60. Wang W-C, Liu S-F, Chang W-T, Shiue Y-L, Hsieh P-F, Hung T-J, et al. The effects of diosgenin in the regulation of renal proximal tubular fibrosis. Exp Cell Res. 2014;232(2):255-62.

61. Ahmed LA, Obaid AZ, Zaki HF, Agha AM. Role of oxidative stress, inflammation, nitric oxide and transforming growth factor-beta in the protective effect of diosgenin in monocrotaline-induced pulmonary hypertension in rats. Eur J Pharmacol. 2014;740:379-87. https://doi.org/10.1 016/j.ejphar.2014.07.026.

62. Tikhonova MA, Yu C-H, Kolosova NG, Gerlinskaya LA, Maslennikova SO, Yudina AV, et al. Comparison of behavioral and biochemical deficits in rats with hereditary defined or D-galactose-induced accelerated senescence: evaluating the protective effects of diosgenin. Pharmacol Biochem Behav. 2014;120:7-16. https://doi.org/10.1016/j.pbb.2014.01.012.

63. Kiasalari Z, Rahmani T, Mahmoudi N, Baluchnejadmojarad T, Roghani M. Diosgenin ameliorates development of neuropathic pain in diabetic rats: involvement of oxidative stress and inflammation. Biomed Pharmacother. 2017;86:654-61. https://doi.org/10.1016/j.biopha.2016.12.068.

64. Zolfaghari F, Rashidi-Monfared S, Moieni A, Abedini D, Ebrahimi A. Improving diosgenin production and its biosynthesis in Trigonella foenumgraecumL. hairy root cultures. Ind Crops Prod. 2020;145:112075. 
65. Lee J, Jung K, Kim YS, Park D. Diosgenin inhibits melanogenesis through the activation of phosphatidylinositol-3-kinase pathway (PI3K) signaling. Life Sci. 2007:81(3):249-54. https://doi.org/10.1016/j.lfs.2007.05.009.

66. Pari L, Monisha P, Jalaludeen AM. Beneficial role of diosgenin on oxidative stress in aorta of streptozotocin induced diabetic rats. Eur J Pharmacol. 2012;691(1-3):143-50. https://doi.org/10.1016/j.ejphar.2012.06.038.

67. Kalailingam P, Kannaian B, Tamilmani E, Kaliaperumal R. Efficacy of natural diosgenin on cardiovascular risk, insulin secretion, and beta cells in streptozotocin (STZ)-induced diabetic rats. Phytomedicine. 2014;21(10): 1154-61. https://doi.org/10.1016/j.phymed.2014.04.005.

68. Sato K, Fujita S, Lemitsu M. Acute administration of diosgenin or dioscorea improves hyperglycemia with increases muscular steroidogenesis in STZinduced type 1 diabetic rats. J Steroid Biochem Mol Biol. 2014;143:152-9. https://doi.org/10.1016/j.jsbmb.2014.02.020.

69. Kanchan DM, Somani GS, Peshattiwar W, Kaikini AA, Sathaye S. Renoprotective effect of diosgenin in streptozotocin induced diabetic rats. Pharmacol Rep. 2016;68(2):370-7. https://doi.org/10.1016/j.pharep.2 015.10.011.

70. Gan Q, Wang J, Hu J, Lou G, Xiong H, Peng C, et al. The role of diosgenin in diabetes and diabetic complications. J Steroid Biochem Mol Biol. 2020;198: 105575. https://doi.org/10.1016/j.jsbmb.2019.105575.

71. Londzin P, Kisiel-Nawrot E, Kocik S, Janas A, Trawczynski M, Cegiela U, et al. Effects of diosgenin on the skeletal system in rats with experimental type 1 diabetes. Biomed Pharmacother. 2020;129:110342. https://doi.org/10.1016/j. biopha.2020.110342.

72. Singh M, Hamid AA, Maurya AK, Prakash O, Khan F, Kumar A, et al. Synthesis of diosgenin analogues as potential anti-inflammatory agents. J Steroid Biochem Mol Biol. 2014;143:323-33. https://doi.org/10.1016/j. jsbmb.2014.04.006.

73. Chen Y, Xu X, Zhang Y, Liu K, Huang F, Liu B, et al. Diosgenin regulates adipokine expression in perivascular adipose tissue and ameliorates endothelial dysfunction via regulation of AMPK. J Steroid Biochem Mol Biol. 2016;155(Part A):155-65.

74. Binesh A, Devaraj SN, Halagowder D. Atherogenic diet induced lipid accumulation induced NFKB level in heart, liver and brain of Wistar rat and diosgenin as an anti-inflammatory agent. Life Sci. 2018;196:28-37. https:// doi.org/10.1016/j.lfs.2018.01.012.

75. Kwon C-S, Sohn HY, Kim SH, Kim JH, Son KH, Lee JS, et al. Anti-obesity effect of Dioscoreanipponica Makino with lipase-inhibitory activity in rodents. Biosci Biotechnol Biochem. 2003;67(7):1451-6. https://doi.org/10.12 71/bbb.67.1451

76. Manivannan J, Shanthakumar J, Rajeshwaran K, Arunagiri P, Balamurugan E. Effect of diosgenin on cardiac tissue lipids, trace elements, molecular changes, TNF- $a$ and IL-6 expression in CRF rats. Biomedi Prevent Nutr. 2013; 3(4):389-92. https://doi.org/10.1016/j.bionut.2013.08.005.

77. Manivannan J, Shanthakumar J, Arunagiri P, Raja B, Balamurugan E. Diosgenin interferes coronary vasoconstriction and inhibits osteochondrogenic transdifferentiation of aortic VSMC in CRF rats. Biochimie. 2014;102:183-7. https://doi.org/10.1016/j.biochi.2014.03.011.

78. Romero-Hernandez L, Merino-Montiel P, Montiel-Smith S, Meza-Reyes S, Vega-Baez JL, Abasolo I, et al. Diosgenin-based thio (seleno) ureas and triazolyl glycoconjugates as hybrid drugs. Antioxidant and Antiproliferative profile. Eur J Med Chem. 2015;99:67-81. https://doi.org/10.1016/j.ejmech.201 5.05.018.

79. Martinez-Gallegos AA, Guerrero-Luna G, Orti-Gonzalez A, Cardenas-Garcia M Bernes S, Hernandez-Linares MG. Azasteroids from diosgenin: synthesis and evaluation of their antiproliferative activity. Steroids. 2020;166:108777. https://doi.org/10.1016/j.steroids.2020.108777.

80. Wu S, Zhao M, Sun Y, Xie M, Le K, Xu M, et al. The potential of diosgenin in treating psoriasis: studies from $\mathrm{HaCaT}$ keratinocytes and imiquimod-induced murine model. Life Sci. 2020;241:117115. https://doi.org/10.1016/j.lfs.2019.11 7115.

81. Raju J, Bird RP. Diosgenin, a naturally occurring furostanol saponin suppresses 3-hydroxy-3-methylglutaryl CoA reductase expression and induces apoptosis in HCT-116 human colon carcinoma cells. Cancer Lett. 2007;255(2):194-204. https://doi.org/10.1016/j.canlet.2007.04.011.

82. Li F, Fernandez PP, Rajendran P, Hui KM, Sethi G. Diosgenin, a steroidal saponin, inhibits STAT2 signaling pathway leading to suppression of proliferation and chemosensitization of human hepatocellular carcinoma cells. Cancer Lett. 2010;292(2):197-207. https://doi.org/10.1016/j.canlet.2 009.12.003.
83. He Z, Chen H, Li G, Zhu H, Gao Y, Zhang L, et al. Diosgenin inhibits the migration of human breast cancer MDA-MB-231 cells by suppressing Vav2 activity. Phytomedicine. 2014;21(6):871-6. https://doi.org/10.1016/j.phymed.2 014.02.002.

84. Guo W, Chen Y, Gao J, Zhong K, Wei H, Li K, et al. Diosgenin exhibits tumor suppressive function via down-regulation of $\mathrm{EZH} 2$ in pancreatic cancer cells. Cell Cycle. 2019;18(15):1745-58. https://doi.org/10.1080/153 84101.2019.1632624.

85. Erdagi SI, Ngwabebhoh FA, Yildiz U. Pickering stabilized nanocellulosealginate: a diosgenin-mediated delivery of quinalizarin as a potent cytoinhibitor in human lung/breast cancer cell lines. Mater Sci Eng C. 2020;109: 110621. https://doi.org/10.1016/j.msec.2019.110621.

86. Hernandez-Vazquez JMV, Lopez-Munoz H, Escobar-Sanchez ML, FloresGuzman F, Weiss-Steider B, Hiario-Martinez JC, et al. Apoptotic, necrotic, and antiproliferative activity of diosgenin and diosgenin glycosides on cervical cancer cells. Eur J Pharmacol. 2020;871:172942. https://doi.org/10.1016/j. ejphar.2020.172942.

87. Michalak O, Krzeczynski P, Cieslak M, Cmoch P, Cybulski M, KrolewskaGolinska K, et al. Synthesis and anti-tumour, immunomodulating activity of diosgenin and tigogenin conjugates. J Steroid Biochem Mol Biol. 2020;198: 105573. https://doi.org/10.1016/j.jsbmb.2019.105573.

88. Zhang J, Wang X, Yang J, Guo L, Wang X, Song B, et al. Novel diosgenin derivatives containing 1,3,4-oxadiazole/thiadiazole moieties as potential antitumor agents: design, synthesis and cytotoxic evaluation. Eur J Med Chem. 2020;186:111897. https://doi.org/10.1016/j.ejmech.2019.111897.

89. Mohamadi-Zarch S-M, Baluchnejadmojarad T, Nourabadi D, Khanizadeh AM, Roghani M. Protective effect of diosgenin on LPS/D-gal-induced acute liver failure in C57BL/6 mice. Microb Pathog. 2020;146:104243. https://doi.org/1 0.1016/j.micpath.2020.104243.

90. Sirotkin AV, Alexa R, Alwasel S, Harrath AH. The phytoestrogen, diosgenin, directly stimulates ovarian cell functions in two farm animal species. Domest Anim Endocrinol. 2019;69:35-41. https://doi.org/10.1016/j.doma niend.2019.04.002

91. Liu W, Zhu M, Yu Z, Yin D, Lu F, Pu Y, et al. Therapeutic effects of diosgenin in experimental autoimmune encephalomyelitis. J Neuroimmunol. 2017;313: 152-60. https://doi.org/10.1016/j.jneuroim.2017.10.018.

92. Tada Y, Kanda N, Haratake A, Tobiishi M, Uchiwa H, Watanabe S. Novel effects of diosgenin on skin aging. Steroids. 2020;74(6):504-11.

93. Erdagi SI, Ngwabebhoh FA, Yildiz U. Genipin crosslinked gelatin-diosgeninnanocellulose hydrogels for potential wound dressing and healing applications. Int J Biol Macromol. 2020;149:651-63. https://doi.org/10.1016/j. ijbiomac.2020.01.279.

\section{Publisher's Note}

Springer Nature remains neutral with regard to jurisdictional claims in published maps and institutional affiliations.

\section{Submit your manuscript to a SpringerOpen ${ }^{\circ}$ journal and benefit from:}

- Convenient online submission

- Rigorous peer review

- Open access: articles freely available online

- High visibility within the field

- Retaining the copyright to your article

Submit your next manuscript at $\boldsymbol{\nabla}$ springeropen.com 